\title{
Retraction
}

\section{Retracted: Type-2 Fuzzy Logic Controller of a Doubly Fed Induction Machine}

\author{
Advances in Fuzzy Systems \\ Received 4 December 2017; Accepted 4 December 2017; Published 15 May 2018 \\ Copyright (C) 2018 Advances in Fuzzy Systems. This is an open access article distributed under the Creative Commons Attribution \\ License, which permits unrestricted use, distribution, and reproduction in any medium, provided the original work is properly \\ cited.
}

Advances in Fuzzy Systems has retracted the article titled "Type-2 Fuzzy Logic Controller of a Doubly Fed Induction Machine" [1]. The article was previously published as "Loukal Keltoum, Benalia Leila, "Type-2 Fuzzy Logic Control of a Doubly-Fed Induction Machine (DFIM)," International Journal of Artificial Intelligence, Vol 4, No 4, 2015. http:// iaescore.com/journals/index.php/IJAI/article/view/6125 [2].

The authors say they did not approve final publication in International Journal of Artificial Intelligence and they do not support the retraction. The IJAI Editor-in-Chief said this was the responsibility of journal staff, but the journal and publisher did not respond to our queries.

\section{References}

[1] K. Loukal and L. Benalia, "Type-2 fuzzy logic controller of a doubly fed induction machine," Advances in Fuzzy Systems-Applications and Theory, vol. 2016, Article ID 8273019, pp. 1-10, 2016.

[2] L. Keltoum and B. Leila, "Type-2 fuzzy logic control of a doublyfed induction machine (DFIM)," International Journal of Artificial Intelligence, vol. 4, no. 4, 2015, http://iaescore.com/journals/ index.php/IJAI/article/view/6125. 